2. Ермолович Д.И. Имена собственные на стыке языков и культур. М.: Валент, 2001. - $198 \mathrm{c}$.

3. Леонович О.А. В мире английских имен. Учебное пособие по лексикологии / 2-е изд., исправленное и дополненное. М: ООО «Издательство АСТ»: ООО «Издательство Астрель», 2002. -160 с.

4. Покровский В.И. Энциклопедический словарь медицинских терминов. М.: Медицина, 2005. - 1592 с.

5. Старичёнок В.Д. Большой лингвистический словарь: [более 3000 лингвистических терминов и понятий]. Ростов-н/Д: Феникс, 2008. - 810 с.

6. Супранская А.В. Общая теория имени собственного. М.: Наука, 1973. - 367 с.

7. Федосюк Ю.А. Русские фамилии: популярный этимологический словарь / Ю.А. Федосюк. 6-е изд., испр. М.: Флинта: Наука, 2006. - 240 с

\title{
Использование сравнительного анализа в былине «Добрыня и Змей» и современного блокбастера «Добрыня Никитич и Змей Горыныч»
}

\author{
Горбатенко М.В., \\ учитель русского языка и литературы, \\ Гимназия № 2, г. Нерюнгри \\ E-mail: Bmw9552@mail.ru
}

Талантливый русский народ еще в далеком прошлом внес в сокровищницу мировой культуры такие богатства, которые возбуждают в нас чувство национальной гордости. Таким богатством, оставленным нам нашими предками, являются и былины особый вид древних русских народных эпических песен исторического содержания. Героические былины дошли к нам из глубины веков.

Уровень информатизации современного общества сейчас очень высок, оно всё больше обращается к научным и публицистическим изданиям, и если современное общество меньше уделяет внимание классике, то былина уже совсем забывается. В качестве возрождения русского фольклора используются разные способы, в том числе и современная мультипликация.

Вряд ли, найдется хоть один ребенок, который не любит смотреть мультики. Мультфильмы для детей - это увлекательное погружение в волшебный мир, яркие впечатления. Современная киноиндустрия, как отечественная, так и зарубежная поражает своим разнообразием, в том числе и мультфильмами.

Многие психологи считают, что герои любимых мультфильмов для детей довольно эффективное воспитательное средство. Герои с экранов активно воздействуют на детское воображение, демонстрируя, как следует себя вести в той или иной ситуации. Дети очень часто имитируют поведение и манеру речи мультяшных героев. Мультфильмы влияют на формирование личности ребенка.

Яркие, зрелищные, образные с одной стороны и простые, ненавязчивые, доступные с другой, мультики близки по своим развивающим, воспитательным возможностям сказке, игре, живому человеческому общению. Персонажи мультипликационных фильмов демонстрируют ребёнку самые разные способы взаимодействия с окружающим миром. Они формируют представления о добре и зле, 
эталоны хорошего и плохого поведения. События, происходящие в мультфильме, позволяют развивать его мышление и воображение, формировать его мировоззрение.

В мультфильме Добрыня Никитич числится на службе Князя Киевского, как и полагается богатырям. Он честно и исправно исполняет свои обязанности, неукоснительно выполняя поручения Князя. Добрыня защищает Княжество Киевское, собирает дань с врагов и подчиненных княжеств, и вообще - делает все, чего требует служба богатыря земли Русской. Добрыня Никитич - состоявшийся семьянин единственный мультипликационный герой такого плана, чья история не заканчивается в конце мультфильма шумной свадьбой. Добрыня уже много лет служит Князю Киевскому, не сомневаясь в обоснованности его поручений. Но очередная просьба Князя вынуждает Добрыню сомневаться в ее честности. Как истинный богатырь, Добрыня Никитич разрешает конфликт, несмотря на все препятствия, сложности и преграды. Добрыня терпеливо относится к своему назойливому и очень болтливому спутнику Елисею, обучая его премудростям богатырской науки. Добрыня - это колоритный, яркий и самый заметный персонаж мультфильма. Он воплощает в себе наиболее характерные черты собирательного образа богатыря. Он по определению несет в себе спокойствие, уверенность, мощь и разумную отвагу. Добрыня Никитич одновременно умеет быть и серьезным и забавным, он способен удивлять своей непосредственностью и искренностью, он восхищает как самый бесхитростный герой мультфильма. Даже в сложной и неоднозначной ситуации мультфильма, Добрыня Никитич остается все таким же честным и добрым богатырем, который сумеет найти правду и среди самых хитроумных махинаций и бесчестных ухищрений. В Добрыне Никитиче можно узнать черты всех известных русских богатырей - искренность, доброту, мужество, спокойствие, доблесть и, разумеется, безграничную отвагу. Сравнение сюжетов двух произведений.

\begin{tabular}{|l|l|}
\hline \multicolumn{1}{|c|}{ Текст былины } & \multicolumn{1}{|c|}{ Мультфильм } \\
\hline $\begin{array}{l}\text { Не упоминается о битве Добрыни с } \\
\text { монголо-татарами }\end{array}$ & $\begin{array}{l}\text { Присутствует фрагмент битвы Добрыни с } \\
\text { монголо-татарами }\end{array}$ \\
\hline $\begin{array}{l}\text { Змей Горыныч после похищения Забавы } \\
\text { забирает её к себе в логово }\end{array}$ & $\begin{array}{l}\text { Змей Горыныч после похищения Забавы } \\
\text { отдаёт её купцу Колывану }\end{array}$ \\
\hline $\begin{array}{l}\text { Похищение племянницы для князя - } \\
\text { полная неожиданность }\end{array}$ & $\begin{array}{l}\text { Князь Владимир идёт на сделку с купцом } \\
\text { и разрешает украсть Забаву }\end{array}$ \\
\hline Добрыня спасает Забаву один & $\begin{array}{l}\text { Вместе с Добрыней Забаву Путятичну } \\
\text { едет спасать гонец Елисей }\end{array}$ \\
\hline Змей - заклятый враг богатыря & $\begin{array}{l}\text { В конце фильма Змей Горыныч помогает } \\
\text { Добрыне }\end{array}$ \\
\hline Заканчивается спасением Забавы & Заканчивается свадьбой Елисея и Забавы \\
\hline
\end{tabular}

Можно сделать вывод, что для былин характерен особый чисто-тонический былинный стих (в основе которого лежит соизмеримость строк по количеству ударений, чем и достигается ритмическое единообразие). Хотя сказители использовали при исполнении былин всего несколько мелодий, они обогащали пение разнообразием интонаций, а также меняли тембр голоса.

В отличие от былины мультфильм сделан в стиле так называемой «пародии на сказку», родоначальником которого является «Шрек» и имеет все его характерные элементы: 
Общий юмористический тон, Ироническое несоответствие некоторых персонажей и действий их сказочным «прототипам» (например, Змей Горыныч оказывается «хорошим парнем» и другом Добрыни).

$>$ Использование клише из популярных фильмов: Змей Горыныч уклоняется от Добрыни «Матрица»,

$>$ Колыван произносит фразу «А теперь — горбатый! Я сказал: горбатый!» «Место встречи изменить нельзя»

$>$ Фраза «В чём сила, брат?», которую произносит Добрыня, позаимствована из дилогии «Брат».

$>$ Фразы «Ну, что делать с ним будем?» и «Голову ему отрубить!» — иллюзия на роман М. Булгакова «Мастер и Маргарита».

$>$ Упоминания о вещах, характерных для нынешнего времени, и оттого комических (Добрыня: «Не знаешь, чего делать? Упал, отжался! Десять раз!.. Двадцать! Вернёмся, я тебя в дружину определю. Там тебя всему научат!» (Имеется в виду современная армия) или же

$>$ Колыван в обмен на услуги обещает Бабе Яге «Дачу под Киевом»).

$>$ Присутствует и герой из мультфильма «Алеша Попович и Тугарин Змей». Портрет Тугарина Змея висит на заднем плане на блокпосту басурманов в главной юрте хана Бекета.

$>$ Кроме того, Елисей проезжает Ростов (город Алёши Поповича), когда доставляет письмо к Добрыне. Также, свадебный стол в финальной сцене проходил именно через Ростов.

$>$ Статуэтка, которую хан Бекет берёт из оброка, — это символ премии «Оскар».

На вопрос «Почему интереснее смотреть мультфильм, чем читать былину?» респонденты дали следующие ответы:

Сложный текст для восприятия; при чтении былины сложно представить героев; былину не будешь самостоятельно читать;

Мультфильм смотреть интересно, много приколов; сразу видишь героев;

Мультфильм можно смотреть много раз самому.

Заключение.

1. На героев былины и мультфильма наложен отпечаток того времени, в которое они были созданы, что делает их отличными друг от друга.

2. Различна цель создания текстов. Былина «Добрыня и Змей» имеет познавательный характер. Блокбастер «Добрыня Никитич и Змей Горыныч» развлекательный характер.

3. Сюжет былины практически не совпадает с сюжетом мультфильма.

4. Данный богатырский блокбастер не доносит до современного зрителя идейного содержания былины «Добрыня и Змей».

5. В современной интерпретации данной былины наблюдается практически полное расхождение с былинным языком. былине.

6. Персонажи в мультфильме трактуются совсем иначе, чем в древнерусской

7. В мультфильм добавлены новые герои, что усложняет сюжет и изменяет взаимоотношения между персонажами.

Мы, русские люди, гордимся своей страной. Нам бесконечно дорого и близко наше настоящее, мы верим в светлое будущее, но ценим и чтим наше прошлое, которое надо помнить для того, чтобы учиться у него. 
Мы считаем, что данный мультфильм смешной, интересный, но больше создан для взрослых, чем для детей. Сначала у детей должно сформироваться патриотическое мировоззрение благодаря русским былинам, а потом можно ради развлечения посмотреть мультипликационный фильм.

\section{Список литературы:}

1. Ашурков В.Н. и другие. Историческое краеведение: Учебное пособие для студентов ист. фак. пед. ин-тов. - 2-е изд. - М.: Просвещение, 1980.

2. Былины / Сост., вступ. ст., подгот. тектов и коммент. Ф.М. Селиванова. - М., 1988.

3. Новый справочник школьника. 5-11 класс. Универсальное пособие. Т.1. СПб.: ИД «ВЕСЬ», 2002.

4. Пропп В.Я. Русский героический эпос. М., 1999.

5. Мифологический словарь / гл. ред. Е.М. Мелетинский. - М.: Советская энциклопедия, 1990.

6. http://dobrinya.3bogatirya.ru , http://ru.wikipedia.org

\section{Психологизм в рассказе Эдгара Аллана По «Падение дома Ашеров»}

Беккер А.В., студент, Технический институт (филиал) Северо-Восточный федеральный университет, 2. Нерюнгри E-mail: becker.alenav@gmail.com

Научный руководитель: к.филол.н. Павлова Т.Л.

Эдгар Аллан По (1809-1849) - знаменитый американский писатель, поэт, представитель американского романтизма. Он является создателем формы современного детектива и жанра психологической прозы. Однако наибольшую известность он приобрел как автор «страшных» рассказов. Именно в этом малом эпическом жанре проявил себя выдающимся мастером художественного слова.

Мистицизм в его рассказах, пугающая и таинственная атмосфера, страшные события перекликаются с жизненными и правдивыми деталями и подробностями, которые создают ощущение реалистичности происходящих событий. Его «страшным» рассказам присущи черты, которые заставляют читателя проникнуться ситуацией ужаса, передаваемые чувствами героев.

По мнению русского литературного критика Николая Васильевича Шелгунова: «Эдгар По психолог, и психолог именно в новейшем понимании этого слова... По первый из писателей-беллетристов явился популяризатором этих психологических процессов, популяризатором таким ясным и логическим, таким твердым и уверенным, каким может явиться только человек, глубоко и внимательно наблюдавший свою собственную душу.» [3, стр.350] 